\title{
Litoribacter ruber gen. nov., sp. nov., an alkaliphilic, halotolerant bacterium isolated from a soda lake sediment
}

\author{
Shi-Ping Tian, ${ }^{1} \dagger$ Yong-Xia Wang, ${ }^{1}$ † Bin $\mathrm{Hu},{ }^{1}$ Xiao-Xia Zhang, ${ }^{2}$ Wei Xiao, ${ }^{1}$ \\ Yun Chen, ${ }^{1}$ Yong-Hong Lai, ${ }^{1}$ Meng-Liang Wen ${ }^{1}$ and Xiao-Long Cui ${ }^{1}$ \\ ${ }^{1}$ The Key Laboratory for Microbial Resources of the Ministry of Education, and Laboratory for \\ Conservation and Utilization of Bio-Resources, Yunnan Institute of Microbiology, Yunnan \\ University, Kunming, Yunnan 650091, PR China \\ ${ }^{2}$ Agricultural Cultural Collection of China, Institute of Agricultural Resources and Regional Planning, \\ Chinese Academy of Agricultural Sciences, Beijing 100080, PR China
}

Correspondence

Xiao-Long Cui

xlcuiynu@yahoo.com.cn or

xlcui@ynu.edu.cn
Bacteria belonging to the phylum Bacteroidetes (Garrity \& Holt, 2001) are considered to be of special importance in aquatic environments. In marine and freshwater environments, bacteria of the phylum Bacteroidetes can be abundant. This phylum includes Gram-negative, heterotrophic bacteria with the capacity to degrade complex organic compounds such as chitin, cellulose (Cottrell \& Kirchman, 2000) and agar (Nedashkovskaya et al., 2003), and they play an important role in carbon cycling in the environment. In volume 4 of Bergey's Taxonomic Outline (Ludwig et al., 2008), the phylum Bacteroidetes includes four classes, 'Bacteroidia', Flavobacteria, 'Sphingobacteria' and 'Cytophagia'. The class 'Cytophagia' includes three families, of which the Cytophagaceae (previously 'Flexibacteraceae') is

†These authors contributed equally to this work.

The GenBank/EMBL/DDBJ accession number for the 16S rRNA gene sequence of strain YIM CH208 ${ }^{\top}$ is GU254164.

A $16 S$ rRNA gene sequence-based maximum-likelihood tree and the absorption spectrum of an acetone/methanol extract of strain YIM $\mathrm{CH}_{20}{ }^{\top}$ are available as supplementary material with the online version of this paper. the largest. In this paper, the characterization and classification of a strain that represents a novel genus-level group of the family Cytophagaceae is reported.

During the investigation of cultured microbial diversity of alkaline environments in Yunnan, south-west China, strain YIM $\mathrm{CH}_{20}{ }^{\mathrm{T}}$ was isolated from a sediment sample collected from the shore of a soda lake in Yongsheng. The strain was isolated by the standard dilution-plating technique on marine agar 2216 (MA; Difco) at $28^{\circ} \mathrm{C}$. Strain YIM CH $208^{\mathrm{T}}$ was subsequently maintained on MA slants and stored as $20 \%(\mathrm{v} / \mathrm{v})$ glycerol suspensions at $-80{ }^{\circ} \mathrm{C}$.

Morphological, physiological and biochemical characteristics of strain YIM $\mathrm{CH} 208^{\mathrm{T}}$ were investigated using routine cultivation on MA. Gram staining was carried out using the standard Gram reaction combined with the $\mathrm{KOH}$ lysis test method (Gregersen, 1978). Cell morphology was examined by light microscopy (Olympus) after staining. Gliding motility was determined using phasecontrast light microscopy (Olympus) after growth on quarter-strength MA solidified with $1 \%$ agar according to 
Bowman (2000). The pigment composition was examined using sonicated cell suspensions, as well as acetone/ methanol $(7: 2, \mathrm{v} / \mathrm{v})$ extracts. Absorption spectra were determined between 300 and $800 \mathrm{~nm}$ with a UV spectrophotometer. Growth was also tested on trypticase soy agar (TSA; BBL) and nutrient agar. Growth at $4-50{ }^{\circ} \mathrm{C}$ and pH 5.0-11.0 was determined in trypticase soy broth (TSB). To test $\mathrm{NaCl}$ tolerance, TSA containing $0-15 \%(\mathrm{w} / \mathrm{v}) \mathrm{NaCl}$ was used. Growth under anaerobic conditions was determined after incubation in an anaerobic jar (GasPak Anaerobic Systems; BBL) on TSA. Degradation of aesculin, cellulose, gelatin, starch and Tweens 20, 40 and 80 was determined according to the protocols described by Cowan \& Steel (1965). Catalase activity was determined by assessing bubble production in $3 \%(\mathrm{v} / \mathrm{v}) \mathrm{H}_{2} \mathrm{O}_{2}$, and oxidase activity was determined using a $1 \%(\mathrm{w} / \mathrm{v})$ solution of tetramethyl- $p$ phenylenediamine (Kovács, 1956). Carbon utilization was tested using artificial seawater medium (Cho \& Giovannoni, 2006) as the basal medium containing each carbon source at a final concentration of $0.5 \%(\mathrm{w} / \mathrm{v}$ or $\mathrm{v} / \mathrm{v})$. Acid production from carbon sources was assessed by using API $50 \mathrm{CH}$ and enzyme activity tests were performed using the API ZYM system (bioMérieux) according to the manufacturer's instructions. Other biochemical tests were carried out with the API 20NE kit (bioMérieux). Antibiotic sensitivities were determined using the disc-diffusion method (Bauer et al., 1966).

Isoprenoid quinones were extracted according to the method of Collins et al. (1977) and analysed by HPLC as described by Tamaoka et al. (1983). Biomass for quantitative fatty acid analysis of the isolate was obtained by scraping cells from TSA plates that had been incubated for 5 days at $\mathrm{pH} 8.5$ and at $28{ }^{\circ} \mathrm{C}$. Analysis of the wholecell fatty acid pattern followed the method of Sasser (1990) using the Microbial Identification System (MIDI).

Genomic DNA extraction, PCR amplification of the $16 \mathrm{~S}$ rRNA gene and sequencing of the purified PCR product were carried out as described previously (Cui et al., 2001). The sequence was compared to those available in GenBank/ EMBL/DDBJ using BLAST (Altschul et al., 1990). Alignments and similarities were obtained by the CLUSTAL_X method. Phylogenetic analyses were carried out using MEGA3 (Kumar et al., 2004). Distances (corrected by Kimura's twoparameter model; Kimura, 1980) were calculated and clustering was performed with the neighbour-joining method (Saitou \& Nei, 1987). A maximum-likelihood (Felsenstein, 1981) tree was generated using the treeing algorithm contained in the PHYLIP package (Felsenstein, 1993). Bootstrap analysis was used to evaluate the tree topology by means of 1000 resamplings (Felsenstein, 1985).

Phylogenetic analysis of the almost-complete 16S rRNA gene sequence (1450 bp) revealed that the isolate occupied a distinct lineage with Echinicola species within the family Cytophagaceae (Fig. 1 and Supplementary Fig. S1, available in IJSEM Online). The topology of the phylogenetic tree constructed using the neighbour-joining algorithm was similar to that of the tree constructed using maximumlikelihood analysis. Sequence analysis revealed that strain YIM $\mathrm{CH} 208^{\mathrm{T}}$ was most closely related to Echinicola pacifica $\mathrm{KMM} 6172^{\mathrm{T}}$ (91.7\% $16 \mathrm{~S}$ rRNA gene sequence

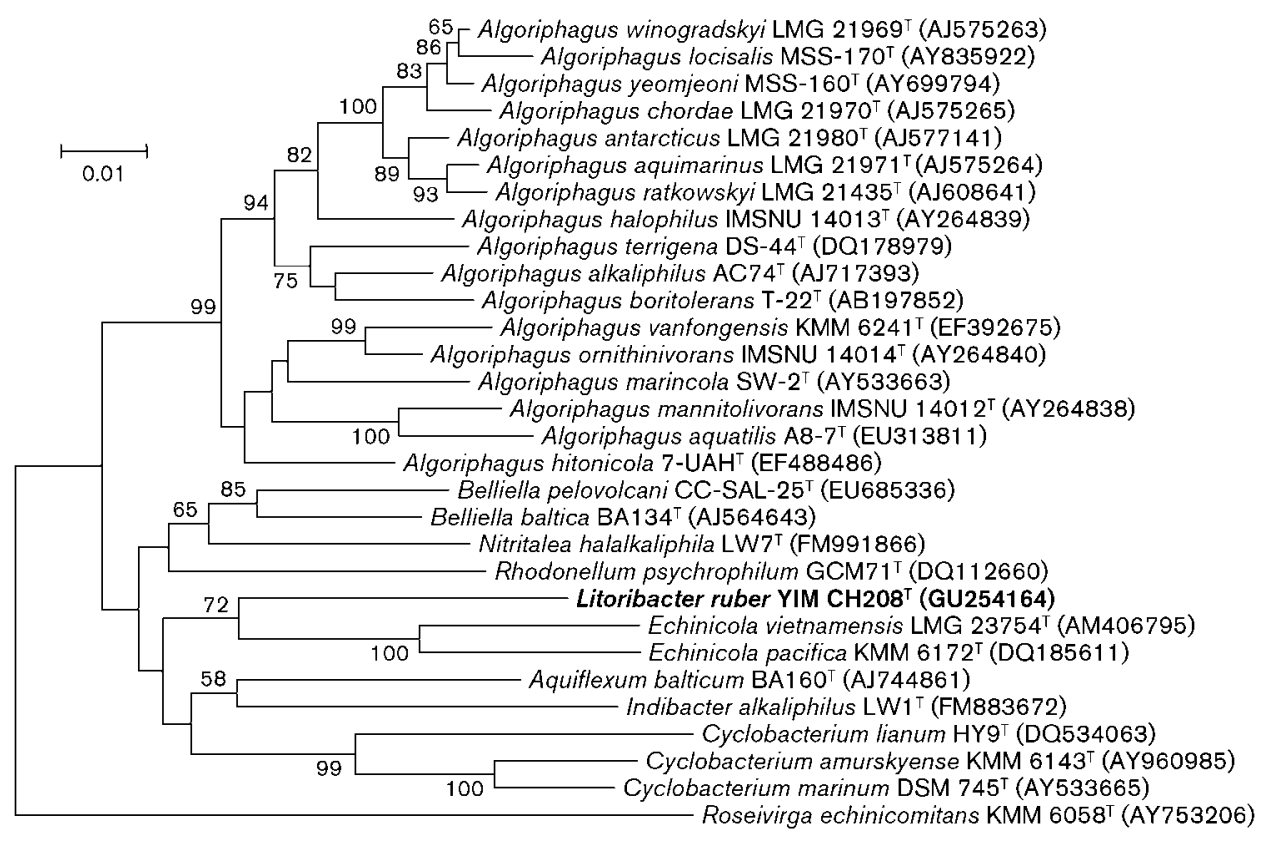

Fig. 1. Neighbour-joining tree based on almost-complete 16S rRNA gene sequences showing the phylogenetic position of strain YIM CH208 ${ }^{\top}$. Numbers at nodes indicate percentages of 1000 bootstrap resamplings; only values $>50 \%$ are given. Bar,

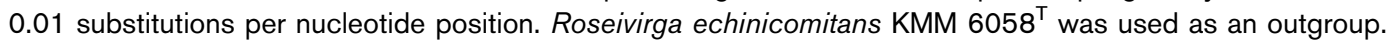


similarity), Rhodonellum psychrophilum GCM $71^{\mathrm{T}}$ (91.6\%), Algoriphagus hitonicola 7-UAH ${ }^{\mathrm{T}}(91.6 \%)$, Echinicola vietnamensis LMG $23754^{\mathrm{T}}(91.3 \%)$ and Belliella baltica $\operatorname{BA} 34^{\mathrm{T}}(91.2 \%)$ and exhibited less than $91 \%$ sequence similarity to other members of the phylum Bacteroidetes. Because of these low similarities, DNA-DNA hybridization experiments were not performed. The rather low levels of sequence similarity also suggest that the isolate belongs to a novel genus-level taxonomic group.

Cells were Gram-negative, catalase- and oxidase-positive rods, $0.3-0.5 \mu \mathrm{m}$ wide and $1.2-1.5 \mu \mathrm{m}$ long. Gliding motility could not be observed by phase-contrast microscopy. Growth occurred on TSA and nutrient agar. Colonies were smooth, circular, convex, opaque and bright red on MA and TSA. Growth did not occur under anaerobic conditions. Growth occurred in media containing 0-9\% (w/ v) $\mathrm{NaCl}$ and optimal growth was observed in media containing $0.5-2.5 \%(\mathrm{w} / \mathrm{v}) \mathrm{NaCl}$. Strain YIM CH $208^{\mathrm{T}}$ grew at $\mathrm{pH} 7.5-10.5$ and showed optimal growth at $\mathrm{pH}$ 8.5. Strain YIM CH $208^{\mathrm{T}}$ was alkaliphilic and halotolerant, but the isolate differs from two recently described alkaliphilic members of the family 'Cyclobacteriaceae', Nitritalea halalkaliphila and Indibacter alkaliphilus (Anil Kumar et al., 2010a, b), in $\mathrm{pH}$ and salinity ranges for growth, nitrate reduction, hydrolysis of gelatin and starch and DNA G $+C$ content (Table 1). The temperature range for growth of strain YIM $\mathrm{CH} 208^{\mathrm{T}}$ was $20-37^{\circ} \mathrm{C}$ and the optimal temperature was $28{ }^{\circ} \mathrm{C}$, whereas the temperature ranges for growth of Echinicola and Rhodonellum species are $6-44^{\circ} \mathrm{C}$ and
0-22 ${ }^{\circ} \mathrm{C}$, respectively (Table 1 ). In addition, strain YIM $\mathrm{CH} 208^{\mathrm{T}}$ differs from Echinicola and Rhodonellum species in the capacity for nitrate reduction and salinity ranges (Table 1). Strain YIM $\mathrm{CH} 208^{\mathrm{T}}$ shows differences from Belliella species with respect to salinity and temperature ranges and DNA G $+\mathrm{C}$ content (Table 1). Other features that distinguish the isolate from its phylogenetic relatives are shown in Table 1.

The genomic DNA $\mathrm{G}+\mathrm{C}$ content was determined by HPLC according to Mesbah et al. (1989) after DNA extraction according to the method of Cui et al. (2001). Genomic DNA from Escherichia coli DH5 $\alpha$ was used as a standard. The DNA $\mathrm{G}+\mathrm{C}$ content of the isolate was $45.1 \mathrm{~mol} \%$.

The major cellular fatty acids of strain YIM CH $208^{\mathrm{T}}$ were iso- $\mathrm{C}_{17: 1} \omega 9 c(19.9 \%), \mathrm{C}_{15: 0} 3-\mathrm{OH}(12.1 \%)$, iso- $\mathrm{C}_{17: 0} 3-$ $\mathrm{OH}(11.3 \%)$, summed feature 3 (iso- $\mathrm{C}_{15: 0} 2-\mathrm{OH}$ and/or $\left.\mathrm{C}_{16: 1} \omega 7 c ; 10.7 \%\right)$ and $\mathrm{C}_{17: 1} \omega 6 c(8.7 \%)$. Strain YIM $\mathrm{CH} 208^{\mathrm{T}}$ could be differentiated chemotaxonomically from closely related species of the family 'Cyclobacteriaceae'. For instance, strain YIM $\mathrm{CH} 208^{\mathrm{T}}$ differs from related species on the basis of the relatively large amount of $\mathrm{C}_{15: 0} 3-\mathrm{OH}$ and small amount of iso- $\mathrm{C}_{15: 0}$ (Table 2). Nitritalea halalkaliphila (Anil Kumar et al., 2010b) differs clearly from strain YIM CH $208^{\mathrm{T}}$ in its fatty acid composition and respiratory quinone (Table 2; Anil Kumar et al., 2010a). The isoprenoid quinones of the strain were MK-7 (97\%) and MK-5 (3\%). The absorbance spectrum of strain YIM $\mathrm{CH} 208^{\mathrm{T}}$ showed a broad peak with maximum absorbance

Table 1. Differential phenotypic properties of Litoribacter ruber gen. nov., sp. nov. YIM CH $208^{\top}$ and its closest phylogenetic neighbours

Taxa: 1, strain YIM CH208 ${ }^{\mathrm{T}}$ (Litoribacter ruber gen. nov., sp. nov.); 2, Echinicola (data from Nedashkovskaya et al., 2006, 2007); 3, Rhodonellum (Schmidt et al., 2006); 4, Belliella (Brettar et al., 2004a; Arun et al., 2009); 5, Algoriphagus (Bowman et al., 2003; Liu et al., 2009); 6, Nitritalea (Anil Kumar et al., 2010b); 7, Indibacter (Anil Kumar et al., 2010a); 8, Aquiflexum (Brettar et al., 2004b). +, Positive; -, negative; v, variable; ND, no data available.

\begin{tabular}{|c|c|c|c|c|c|c|c|c|}
\hline Characteristic & 1 & 2 & 3 & 4 & 5 & 6 & 7 & 8 \\
\hline Motility & - & + & - & - & - & - & - & - \\
\hline $\mathrm{pH}$ range for growth & $7.5-10.5$ & $\mathrm{ND}$ & $7.5-10.7$ & $6-9 / 6-10$ & $\mathrm{~V}$ & $7.5-12$ & $7.5-12$ & $7-9$ \\
\hline \multicolumn{9}{|l|}{ Temperature for growth $\left({ }^{\circ} \mathrm{C}\right)$} \\
\hline Range & $20-37$ & $6-44$ & $0-22$ & $4-40$ & $4-42$ & $25-40$ & $15-40$ & $4-40$ \\
\hline Optimum & 28 & $25-28 / 30-32$ & 5 & $25 / 37$ & $\mathrm{~V}$ & 37 & $30-37$ & 30 \\
\hline Nitrate reduction to nitrite & + & - & - & V & $\mathrm{v}$ & - & + & + \\
\hline \multicolumn{9}{|l|}{ Hydrolysis of: } \\
\hline
\end{tabular}


Table 2. Cellular fatty acid compositions of Litoribacter ruber gen. nov., sp. nov. YIM $\mathrm{CH}_{20}{ }^{\top}$ and its closest phylogenetic neighbours

Taxa: 1, YIM CH208 ${ }^{\mathrm{T}}$ (Litoribacter ruber gen. nov., sp. nov.); 2, Echinicola (data from Nedashkovskaya et al., 2006, 2007); 3, Rhodonellum (Schmidt et al., 2006); 4, Belliella (Arun et al., 2009); 5, Algoriphagus (Bowman et al., 2003; Liu et al., 2009); 6, Nitritalea (Anil Kumar et al., 2010b); 7, Indibacter (Anil Kumar et al., 2010a); 8, Aquiflexum (Kämpfer et al., 2010). Values are percentages of total fatty acids; fatty acids present at less than $1 \%$ in all strains are not shown. Values for predominant fatty acids $(\geqslant 5 \%)$ are in bold; NA, not applicable (reported as a component of a summed feature); - , not detected/not reported.

\begin{tabular}{|c|c|c|c|c|c|c|c|c|}
\hline Fatty acid & 1 & 2 & 3 & 4 & 5 & 6 & 7 & 8 \\
\hline anteiso- $\mathrm{C}_{14: 0}$ & - & - & - & - & - & 5.0 & - & - \\
\hline iso- $\mathrm{C}_{15: 0}$ & - & $17.3-20.0$ & 7.6 & $23.9-31.2$ & 13.4 & - & 47.9 & 11.2 \\
\hline anteiso- $\mathrm{C}_{15: 0}$ & 4.7 & $1.4-2.8$ & 1.4 & $2.9-5.4$ & 3.8 & - & 6.7 & 16.5 \\
\hline iso- $\mathrm{C}_{15: 1} \mathrm{~F}$ & - & - & - & - & - & - & 1.6 & - \\
\hline iso- $\mathrm{C}_{16: 0}$ & 1.7 & $1.1-1.2$ & 2.2 & $1.9-2.2$ & 2.7 & - & 2.1 & 4.7 \\
\hline iso- $\mathrm{C}_{16: 1} \mathrm{H}$ & 1.7 & $0.8-1.0$ & 7.3 & $1.7-2.9$ & - & - & 0.8 & 11.1 \\
\hline iso- $\mathrm{C}_{17: 0}$ & 2.5 & $0-1.0$ & 0.2 & $0.6-0.7$ & 0.2 & - & 2.4 & - \\
\hline iso $\mathrm{C}_{19: 1} \mathrm{I}$ & - & - & - & - & - & - & - & 1.5 \\
\hline $\mathrm{C}_{15: 1} \omega 6 c$ & 3.1 & $1.1-1.2$ & 2.7 & $1.2-6.4$ & 0.1 & - & 1.5 & 1.0 \\
\hline $\mathrm{C}_{16: 1} \omega 7 c$ & $\mathrm{NA}$ & NA & $\mathrm{NA}$ & NA & 34.1 & - & - & $\mathrm{NA}$ \\
\hline $\mathrm{C}_{16: 1} \omega 9 c$ & - & - & - & - & - & 5.1 & - & - \\
\hline iso- $\mathrm{C}_{17: 1} \omega 5 c$ & - & - & - & - & 1.2 & - & - & - \\
\hline iso- $\mathrm{C}_{17: 1} \omega 7 c$ & - & - & - & - & 3.9 & - & - & - \\
\hline iso- $\mathrm{C}_{17: 1} \omega 9 c$ & 19.9 & $4.4-6.9$ & 17.5 & $4.4-7.3$ & - & - & 1.0 & 5.3 \\
\hline anteiso- $C_{17: 1} \omega 9 c$ & - & - & - & - & - & - & - & 1.1 \\
\hline $\mathrm{C}_{17: 1} \omega 6 c$ & 8.7 & $4.3-4.8$ & 6.8 & $5.6-7.9$ & 0.5 & - & 1.2 & 5.3 \\
\hline $\mathrm{C}_{17: 1} \omega 8 c$ & 1.6 & - & 0.2 & $1.0-1.1$ & - & - & 0.4 & - \\
\hline $\mathrm{C}_{18: 1} \omega 9 c$ & - & - & - & - & - & 8.0 & - & - \\
\hline iso- $\mathrm{C}_{15: 0} 2-\mathrm{OH}$ & NA & NA & NA & $0.9-1.2^{*}$ & 4.2 & - & - & NA \\
\hline iso- $\mathrm{C}_{15: 0} 3-\mathrm{OH}$ & 4.1 & $3.4-5.0$ & 3.7 & $3.9-4.2$ & 0.3 & - & 1.2 & 4.3 \\
\hline $\mathrm{C}_{18: 0} 3-\mathrm{OH}$ & - & - & - & - & - & 1.9 & - & - \\
\hline anteiso- $\mathrm{C}_{17: 1} \mathrm{~B} /$ iso- $\mathrm{C}_{17: 1} \mathrm{I} \dagger$ & - & $0-5.0$ & - & $0-4.4$ & - & - & - & $5.9 \ddagger$ \\
\hline $\mathrm{C}_{16: 1} \omega 7 c /$ iso- $\mathrm{C}_{15: 0} 2-\mathrm{OH} \dagger$ & 10.7 & 34.5 & 12.6 & $12.3-12.7$ & - & - & - & 8.7 \\
\hline $\mathrm{C}_{14: 0} 2-\mathrm{OH} /$ iso- $\mathrm{C}_{15: 0} 2-\mathrm{OH} \dagger$ & - & - & 6.5 & - & - & - & - & - \\
\hline Not identified & - & - & - & - & - & - & 12.5 & 1.1 \\
\hline
\end{tabular}

*Arun et al. (2009) reported iso- $\mathrm{C}_{15: 0}$ 2-OH both as a component of summed feature 3 and as a distinct fatty acid. $\uparrow$ Summed features: groups of two or three fatty acids that cannot be separated by GC with the MIDI system.

¥Reported as anteiso- $\mathrm{C}_{17: 1}$ B by Kämpfer et al. (2010).

at $473 \mathrm{~nm}$ with two shoulders at 450 and $504 \mathrm{~nm}$ (Supplementary Fig. S2), which suggests the presence of carotenoids. Bacteriochlorophyll $a$ was not synthesized.
The close relative Rhodonellum psychrophilum showed a similar carotenoid absorption spectrum, with absorption peaks at 460, 489 and $517 \mathrm{~nm}$ (Schmidt et al., 2006). 
The data from our phenotypic, chemotaxonomic, genotypic and phylogenetic analyses suggest that the isolate cannot be assigned to any known taxon. Differences in some phenotypic features, as well as fatty acid compositions and 16S rRNA gene sequences, differentiate the isolate clearly from phylogenetically related taxa (Table 1) and indicate that the isolate represents a novel genus and species, for which the name Litoribacter ruber gen. nov., sp. nov. is proposed.

\section{Description of Litoribacter gen. nov.}

Litoribacter (Li.to.ri.bac'ter. L. n. litus -oris shore, beach, strand; N.L. masc. n. bacter rod; N.L. masc. n. Litoribacter rod from the shore).

Cells are Gram-negative, rod-shaped and oxidase- and catalase-positive. Growth is strictly aerobic. Major fatty acids are iso- $\mathrm{C}_{17: 1} \omega 9 \mathrm{c}, \mathrm{C}_{15: 0} 3-\mathrm{OH}$, iso- $\mathrm{C}_{17: 0}$ 3- $\mathrm{OH}$, summed feature 3 (iso- $\mathrm{C}_{15: 0} 2-\mathrm{OH}$ and/or $\mathrm{C}_{16: 1} \omega 7 c$ ) and $\mathrm{C}_{17: 1} \omega 6 c$. Predominant isoprenoid quinone is MK-7. Cells contain carotenoids but no bacteriochlorophyll $a$. The genus Litoribacter is a member of the phylum Bacteroidetes. The type species is Litoribacter ruber.

\section{Description of Litoribacter ruber sp. nov.}

Litoribacter ruber (ru'ber. L. masc. adj. ruber rose coloured, red).

Main characteristics are as given for the genus. In addition, cells are $0.3-0.5 \times 1.2-1.5 \mu \mathrm{m}$. Colonies are circular, 2$3 \mathrm{~mm}$ in diameter, convex, smooth and bright red. Grows at $20-37{ }^{\circ} \mathrm{C}$ (optimum $28{ }^{\circ} \mathrm{C}$ ) and $\mathrm{pH}$ 7.5-10.5 (optimum $\mathrm{pH} 8.5$ ). Growth occurs at $0-9 \%(\mathrm{w} / \mathrm{v}) \mathrm{NaCl}$ (optimum $0.5-2.5 \%)$. Degrades aesculin, starch and Tween 40. Does not hydrolyse gelatin, cellulose (CM-cellulose) or Tween 20 or 80 . In API $50 \mathrm{CH}$ test strips, acid is produced from amygdalin, aesculin, cellobiose, L-fucose, gentiobiose, Dglucose, lactose, maltose, D-mannose, methyl $\alpha$-D-glucopyranoside, raffinose, salicin, starch and sucrose. In API 20NE, tests positive for nitrate reduction, aesculin hydrolysis, arginine dihydrolase, urease and $\beta$-galactosidase. Can utilize fructose, galactose, glycerol, glucose, lactose, D-mannitol, D-mannose, raffinose, ribose, starch, sucrose, D-sorbitol, trehalose, acetate, benzoate, citrate and malate as sole carbon sources. In API ZYM, tests positive for $\alpha$-galactosidase, alkaline and acid phosphatases, esterase (C4), esterase lipase (C8), lipase (C14), leucine arylamidase, valine arylamidase, cystine arylamidase, trypsin, $\alpha$ chymotrypsin, naphthol-AS-BI-phosphohydrolase, $\alpha$ - and $\beta$-glucosidases and $N$-acetyl- $\beta$-glucosaminidase, but negative for $\beta$-galactosidase, $\alpha$-mannosidase, $\alpha$-fucosidase and $\beta$-glucuronidase. Cells are sensitive to ( $\mu \mathrm{g}$ per disc unless indicated) vancomycin (30), norfloxacin (10), erythromycin (15), novobiocin (5), tetracycline (30), ampicillin (10), amikacin (30), ciprofloxacin (5), penicillin (10 IU) and clindamycin (2), but resistant to tobramycin (10). The DNA G $+\mathrm{C}$ content of the type strain is $45.1 \mathrm{~mol} \%$.
The type strain, YIM CH208 ${ }^{\mathrm{T}}\left(=\mathrm{ACCC} 05414^{\mathrm{T}}=\mathrm{KCTC}\right.$ $22899^{\mathrm{T}}$ ), was isolated from a sediment sample collected from the shore of a soda lake in Yunnan, south-west China.

\section{Acknowledgements}

This work was supported by grants from the Ministry of Environmental Protection of China (National Key Sciences and Technology Program for Water Solutions, 2008ZX07102-004), the National Natural Science Foundation of China (NSFC) (30860013, 31000003), the Ministry of Science and Technology of China 863 Program (2007AA021306), the Yunnan Provincial Sciences and Technology Department (2005PY01-1, 2009CD012, 2009DA002) and Yunnan University (2008YB005, 2009C14Q, 2010C02Q). We are grateful to $\mathrm{Mr} \mathrm{Yu}-$ Yun Liu for his help during sampling.

\section{References}

Altschul, S. F., Gish, W., Miller, W., Myers, E. W. \& Lipman, D. J. (1990). Basic local alignment search tool. J Mol Biol 215, 403-410.

Anil Kumar, P., Srinivas, T. N. R., Madhu, S., Manorama, R. \& Shivaji, S. (2010a). Indibacter alkaliphilus gen. nov., sp. nov., an alkaliphilic bacterium isolated from a haloalkaline lake. Int J Syst Evol Microbiol 60, 721-726.

Anil Kumar, P., Srinivas, T. N. R., Pavan Kumar, P., Madhu, S. \& Shivaji, S. (2010b). Nitritalea halalkaliphila gen. nov., sp. nov., an alkaliphilic bacterium of the family 'Cyclobacteriaceae', phylum Bacteroidetes. Int J Syst Evol Microbiol 60, 2320-2325.

Arun, A. B., Young, C.-C., Chen, W.-M., Hung, M.-H., Lai, W.-A., Chou, J.-H., Rekha, P. D., Shen, F.-T. \& Su, S. P. (2009). Belliella pelovolcani sp. nov., isolated from a mud-volcano in Taiwan. Int J Syst Evol Microbiol 59, 2534-2537.

Bauer, A. W., Kirby, W. M. M., Sherris, J. C. \& Turck, M. (1966). Antibiotic susceptibility testing by a standardized single disk method. Am J Clin Pathol 45, 493-496.

Bowman, J. P. (2000). Description of Cellulophaga algicola sp. nov., isolated from the surfaces of Antarctic algae, and reclassification of Cytophaga uliginosa (ZoBell and Upham 1944) Reichenbach 1989 as Cellulophaga uliginosa comb. nov. Int J Syst Evol Microbiol 50, 18611868.

Bowman, J. P., Nichols, C. M. \& Gibson, J. A. (2003). Algoriphagus ratkowskyi gen. nov., sp. nov., Brumimicrobium glaciale gen. nov., sp. nov., Cryomorpha ignava gen. nov., sp. nov. and Crocinitomix catalasitica gen. nov., sp. nov., novel flavobacteria isolated from various polar habitats. Int J Syst Evol Microbiol 53, 1343-1355.

Brettar, I., Christen, R. \& Höfle, M. G. (2004a). Belliella baltica gen. nov., sp. nov., a novel marine bacterium of the CytophagaFlavobacterium-Bacteroides group isolated from surface water of the central Baltic Sea. Int J Syst Evol Microbiol 54, 65-70.

Brettar, I., Christen, R. \& Höfle, M. G. (2004b). Aquiflexum balticum gen. nov., sp. nov., a novel marine bacterium of the CytophagaFlavobacterium-Bacteroides group isolated from surface water of the central Baltic Sea. Int J Syst Evol Microbiol 54, 2335-2341.

Cho, J. C. \& Giovannoni, S. J. (2006). Pelagibaca bermudensis gen. nov., sp. nov., a novel marine bacterium within the Roseobacter clade in the order Rhodobacterales. Int J Syst Evol Microbiol 56, 855-859.

Collins, M. D., Pirouz, T., Goodfellow, M. \& Minnikin, D. E. (1977). Distribution of menaquinones in actinomycetes and corynebacteria. J Gen Microbiol 100, 221-230.

Cottrell, M. T. \& Kirchman, D. L. (2000). Community composition of marine bacterioplankton determined by $16 \mathrm{~S}$ rRNA gene clone 
libraries and fluorescence in situ hybridization. Appl Environ Microbiol 66, 5116-5122.

Cowan, S. T. \& Steel, K. J. (1965). Manual for the Identification of Medical Bacteria. London: Cambridge University Press.

Cui, X. L., Mao, P. H., Zeng, M., Li, W. J., Zhang, L. P., Xu, L. H. \& Jiang, C. L. (2001). Streptomonospora salina gen. nov., sp. nov., a new member of the family Nocardiopsaceae. Int J Syst Evol Microbiol 51, 357-363.

Felsenstein, J. (1981). Evolutionary trees from DNA sequences: a maximum likelihood approach. J Mol Evol 17, 368-376.

Felsenstein, J. (1985). Confidence limits on phylogenies: an approach using the bootstrap. Evolution 39, 783-791.

Felsenstein, J. (1993). PHYLIP (phylogeny inference package) version 3.5. Distributed by the author. Department of Genome Sciences, University of Washington, Seattle, USA.

Garrity, G. M. \& Holt, J. G. (2001). The road map to the Manual. In Bergey's Manual of Systematic Bacteriology, 2nd edn, vol. 1, pp. 119166. Edited by D. R. Boone, R. W. Castenholz \& G. M. Garrity. New York: Springer.

Gregersen, T. (1978). Rapid method for distinction of Gram-negative from Gram-positive bacteria. Eur J Appl Microbiol Biotechnol 5, 123 127.

Kämpfer, P., Young, C.-C., Chen, W.-M., Rekha, P. D., Fallschissel, K., Lodders, N., Chou, J.-H., Shen, F.-T., Frischmann, A. \& other authors (2010). Fontibacter flavus gen. nov., sp. nov., a member of the family 'Cyclobacteriaceae', isolated from a hot spring. Int J Syst Evol Microbiol 60, 2066-2070.

Kimura, M. (1980). A simple method for estimating evolutionary rates of base substitutions through comparative studies of nucleotide sequences. J Mol Evol 16, 111-120.

Kovács, N. (1956). Identification of Pseudomonas pyocyanea by oxidase reaction. Nature 178, 703-704.

Kumar, S., Tamura, K. \& Nei, M. (2004). MEGA3: integrated software for molecular evolutionary genetics analysis and sequence alignment. Brief Bioinform 5, 150-163.
Liu, Y., Li, H., Jiang, J. T., Liu, Y. H., Song, X. F., Xu, C. J. \& Liu, Z. P. (2009). Algoriphagus aquatilis sp. nov., isolated from a freshwater lake. Int J Syst Evol Microbiol 59, 1759-1763.

Ludwig, W., Euzéby, J. \& Whitman, W. B. (2008). Draft taxonomic outline of the Bacteroidetes, Planctomycetes, Chlamydiae, Spirochaetes, Fibrobacteres, Fusobacteria, Acidobacteria, Verrucomicrobia, Dictyoglomi, and Gemmatimonadetes. Bergey's Taxonomic Outlines, vol. 4. http:// www.bergeys.org/outlines/Bergeys_Vol_4_Outline.pdf

Mesbah, M., Premachandran, U. \& Whitman, W. B. (1989). Precise measurement of the $\mathrm{G}+\mathrm{C}$ content of deoxyribonucleic acid by highperformance liquid chromatography. Int J Syst Bacteriol 39, 159-167.

Nedashkovskaya, O. I., Suzuki, M., Vysotskii, M. V. \& Mikhailov, V. V. (2003). Reichenbachia agariperforans gen. nov., sp. nov., a novel marine bacterium in the phylum Cytophaga-FlavobacteriumBacteroides. Int J Syst Evol Microbiol 53, 81-85.

Nedashkovskaya, O. I., Kim, S. B., Vancanneyt, M., Lysenko, A. M., Shin, D. S., Park, M. S., Lee, K. H., Jung, W. J., Kalinovskaya, N. I. \& other authors (2006). Echinicola pacifica gen. nov., sp. nov., a novel flexibacterium isolated from the sea urchin Strongylocentrotus intermedius. Int J Syst Evol Microbiol 56, 953-958.

Nedashkovskaya, O. I., Kim, S. B., Hoste, B., Shin, D. S., Beleneva, I. A., Vancanneyt, M. \& Mikhailov, V. V. (2007). Echinicola vietnamensis sp. nov., a member of the phylum Bacteroidetes isolated from seawater. Int J Syst Evol Microbiol 57, 761-763.

Saitou, N. \& Nei, M. (1987). The neighbor-joining method: a new method for reconstructing phylogenetic trees. Mol Biol Evol 4, 406425.

Sasser, M. (1990). Identification of bacteria by gas chromatography of cellular fatty acids. USFCC Newsl 20, 16.

Schmidt, M., Priemé, A. \& Stougaard, P. (2006). Rhodonellum psychrophilum gen. nov., sp. nov., a novel psychrophilic and alkaliphilic bacterium of the phylum Bacteroidetes isolated from Greenland. Int J Syst Evol Microbiol 56, 2887-2892.

Tamaoka, J., Katayama-Fujimura, Y. \& Kuraishi, H. (1983). Analysis of bacterial menaquinone mixtures by high performance liquid chromatography. J Appl Bacteriol 54, 31-36. 